\title{
ORBIT AND AXIS: CARL F. H. HENRY ON REVELATION AND EDUCATION
}

\author{
JONATHAN WOOD* \\ Cedarville University
}

\begin{abstract}
Carl F. H. Henry serves as a fruitful resource for the integration of faith and learning. The central issue in Christian scholarship is to properly associate the revelation of God with the knowledge of God's world across all academic disciplines. The particular effort of this article is to demonstrate the clarity Henry provides as it relates to general revelation, special revelation, and knowledge explored in a comprehensive university setting. Building on Henry's clarity, an orientation of knowledge to Jesus Christ, a proposal for the resulting vision for Christian scholarship, and habits of Christian educational institutions follows.
\end{abstract}

KEYWORDS: General Revelation, Special Revelation, Christian Education, Carl F. H. Henry, Scholarship

Let me begin by asking you to construct a mental image of an axis around which other objects find their orbit. Perhaps this exercise draws to mind a model of the solar system with the sun at the center and the planets hanging in orbit around that axis. Or, perhaps a mobile above a baby's crib comes to mind with the calming motion of figures suspended in orbit. In order to understand Carl F. H. Henry's approach to divine revelation and the world of higher education we will return to this image in due time. However, we must first consider the rationale for listening to a voice formerly more familiar in the halls of Christian educational institutions. Carl F. $\mathrm{H}$. Henry provides a wealth of insight into the nature and mission of higher education in light of the lordship of Christ over his creation and the triune God's self-disclosure in general and special revelation. This article will provide an overview of Henry's theology of revelation and draw implications of that theology's relevance for higher education.

* JONATHAN WOOD (PhD 2015, Southwestern Baptist Theological Seminary) is Vice President for Student Life and Christian Ministries and Associate Professor of Theological Studies at Cedarville University. Email: jonwood@cedarville.edu. 


\section{Carl F. H. Henry's Voice}

Henry holds privilege as an elite evangelical theologian, not only through his theological writings, but also through his position as the theologianfigurehead of the neo-evangelical movement in post-World War II America. Writing about Henry, the narrative theologian Gabriel Fackre noted, "[i]f the twentieth century evangelical renaissance in North America has produced a Michelangelo, that exemplar is surely Carl Henry' (Fackre 1993: 171). Henry's place as the 'Dean of Evangelical Theologians' was acquired through his unrelenting insistence on promoting a theological vision that would produce a personal Christian faith able to speak intelligently to every aspect of culture (Olsen 2005: 41). In his attempt to create a full orbed movement marked by spiritual and academic potency, Henry published key works that interacted with the fields of biblical studies, theological studies, and apologetics.

In particular, Henry's well-known work, which is considered his magnum opus, God, Revelation, and Authority (GRA), provides his account of the epistemological basis for Christian belief grounded in the revealed Word of God (Henry 1976: 2, 267). GRA seeks to provide a biblically faithful explication of the doctrines of God and revelation, all the while taking seriously the impact of modernity on these subjects in contemporary theology. Henry's eminence is resultant of the fact that his six-volume work, as Trueman references, is the "most exhaustive evangelical statement on these issues to have been produced in the twentieth century and, upon its publication, marked the pinnacle of Henry's career as intellectual evangelical leader and spokesperson' (Trueman 2000: 49). The need of the hour in Henry's estimation was to understand the world the Enlightenment produced from every angle and respond to all facets in a competent manner. Henry's concern for the doctrine of revelation and the doctrine of God extended beyond their consideration as heads of doctrine to developing their implications for the broader outworking of theology, including in the realm of higher education.

So why pay attention to this theologian in the context of comprehensive education? Henry staked his ground in favor of evangelical education early in his career and never deviated from providing an apologetic for top-flight scholarship by Christians in every field of learning. Henry's passion regarding education grew from his theology and his philosophy of ministry. Henry's burden to demonstrate the comprehensive explanatory ability of the biblically revealed world-life view led him to deep convictions and ambitions related to higher education. Throughout his career, Henry was keen to engage the world of higher education for three reasons.

First, Henry viewed education as the field in which Jesus Christ could truly be demonstrated as the axis around which all of creation orbits, just as 
Paul states in Colossians 1:15-17. In light of the preeminence of Christ, comprehensive education is a means to worship the creator. Additionally, Henry viewed the intellectual demonstration of the Lordship of Christ as the unifying principle of all reality. Second, Henry viewed the modern situation of education as one in which secular presuppositions are advanced upon the social order. Most citizens live naïve of the deep social brokenness that the seeds of secularism in higher education will produce in society. He believed education to be an indispensable feature in making Christianity intelligible in the modern secular world and reversing the tide of secularism for the sake of social flourishing in Western society. Henry states, 'The conflict of ideas and their resolution in the classroom remains the critical center of serious learning. Not doing the truth will condemn us, but not knowing it-when in fact earnest education can uncover it-is worse still, since it dooms us to doing the right thing only by chance, if at all' (Henry 1988: 93). Third, he saw education as an essential element of a multi-pronged strategy for evangelicals to accomplish the reception of the Gospel in an increasingly secularized age. To this end, Henry states, 'The college or university is the intellectually critical axis of society, and if the Christian takes seriously his citizenship in two worlds he dare not be disengaged from either' (Henry 1988: 93).

Henry's vision for Christian education would lead to a specific ambition of establishing an academically prestigious, research oriented, doctoral degree granting, comprehensive university (Strachan 2015: 127-157; Rosell 2008: 208-211). While unfulfilled, this lifelong ambition of establishing such an institution illustrates the priorities of the educator-theologian.

\section{General Revelation and Special Revelation}

Henry's focus on epistemology, revelation, and education provides fruitful backdrop for discerning the nature and role of God's revelation as it relates to the pursuit of knowledge about the world. In what way is the human pursuit of knowledge within a field of study related to knowledge of God Himself? Is knowledge acquired in physics, biology, philosophy, history, and psychology equivalent to accessing the general revelation of God? How does the authority and sufficiency of the Scripture impact the interpretation of knowledge attained in the aforementioned fields? These questions are essential to the task of Christian education and the answers are built on one's theology of revelation.

\section{Why Speak of Revelation?}

Who God is, how He has revealed himself, and how we know that revelation are not three isolated theological issues, but are actually three aspects of one issue that must be dealt with to articulate a Christian view of the 
world. Henry states it this way: 'Wherever God is acknowledged, the question whether He has spoken, and what if anything He has said, belongs in the forefront' (Henry 1957: 253). What makes for a distinctly Christian view of the world? Henry's answer to this question is that the centrality of God and His nature carry implications both for what humanity knows and how humanity knows. The presuppositions of the Christian worldview, according to Henry, are:

(A1) There exists a God who is capable and desirous of revealing himself,

(A2) Humans are capable, or may be made capable, of receiving divine revelation, and

(A3) Human language is capable of transmitting divine revelation.

Part and parcel with inquiry about God is the existence of His communication and humanity's ability to understand that communication. Therefore, when we start with revelation, we are actually beginning with matters of the doctrine of God and His nature.

God exists, and He has communicated. In light of this fact, one of the earliest theological issues to engage is the nature of God's revelation. In the broadest sense, God's revelation is His multiform disclosure of Himself to humanity. Henry states, 'Revelation is a divinely initiated activity, God's free communication by which he alone turns his personal privacy into a deliberate disclosure of his reality' (Henry 1976: 2, 17). On the notion that God has revealed Himself, Henry states:

The category of revelation is therefore broader than the category of the spoken and written words of Scripture, since it covers special historic events which the Bible normatively interprets, including the incarnation, and moreover, extends beyond special revelation to include the sphere of general revelation as well... Nothing less may be said than that the category of revelation is identical with the whole unveiling of God, whatever forms that disclosure may assume (Henry 1957: 255).

Modern evangelicals stand in an ancient heritage by considering revelation as a presupposition of the Christian worldview. Athanasius states,

For what profit would there be for those who were made, if they did not know their own Maker? Or how would they be rational, not knowing the Word of the Father, in whom they came to be? For they would not have differed at all from the irrational creatures if they had known nothing more than the terrestrial animals. And why would God have made those by whom he did not wish to be known? (Athanasius 2011: 60). 
Viewing the above matters as the starting point for all of theology and the truths which distinguish Christian approaches to knowledge from all others, Henry outlines the nature of revelation under 15 theses, across 3,500 pages in GRA, not to mention numerous other articles and books. The question arises then, how has God revealed Himself? At this point Henry moves from the broad concept of a God who has voluntarily revealed Himself to explore how He has done so under two categories: general revelation and special revelation.

\section{What is General Revelation?}

General revelation is the disclosure to all people of God's eternal existence as discerned through creation and the existence of human moral conscience rooted in the imago dei. A constant and subtle communication from God stands in support of the Scriptures. Henry articulates it this way, '[A]longside of special divine revelation in its Scriptural form, HebrewChristian theology emphasizes as an indispensable corollary the general divine revelation given in nature, history and conscience' (Henry 1957: 254). The Bible communicates this divine general revelation in Romans 1 , Romans 2, Psalm 19, and Acts 17. The primary inquiry regarding general revelation is to determine, 'If something about God is being revealed, what is the content of that revelation?' Following Henry's take on the biblical answer to this inquiry, we will consider misconceptions of general revelation he sought to correct.

\section{Content of General Revelation: The Divine Power and Eternal Nature of God (Romans 1)}

Humanity stands in unavoidable and essential relationship to the Creator, regardless of explicit acknowledgement of this reality by the individual. One manner in which God's revelation in creation expresses His existence is that humanity lives all of life in an answering relationship. G. C. Berkouwer states, 'Man is not situated in a silent, purposeless and senseless world in which no voice whatever addresses him. Much rather, over against nihilism it must be asserted that human life bears an answering character. Although man is not conscious of it, his whole life is a reply, even to the deepest aspects of his religion' (Berkouwer 1958: 16-17).

The background of an 'answering' nature of humanity implies that all people have received an address that warrants response. What is this address, particularly in light of peoples and societies who do not possess or heed attention to the written Word of God? Nature itself is God's address:

Nature is not some theologically insignificant material context in which man lives and works. While nature has no will of its own, no capacity for moral choice, its forms and structures are nonetheless given and sustained by the Logos of God. 
Pervaded by God's divine presence and power it is an intelligible order serving moral purposes and a realm of providential fulfillment (Henry 1976: 2, 97).

Yet, caution is warranted to clarify these comments about the theological nature of creation. General revelation should not be taken to convey that God is one with His creation. God remains wholly distinct and transcendent from creation, and it is only by his voluntary communication through the orders of creation that general revelation finds its existence. The Scriptures take care to portray that the universe is not a direct self-revelation of God, as though it were emanating from Him and a part of Him, but rather He has ordered it in such a way that it bears testimony to Him. Nature is not deified in its general revelatory capacity, but God has chosen to provide indication of His existence through His chosen design.

It is essential to note the limited scope of content revealed about God according to Romans 1. The revelatory content of the divine existence and eternal nature of God communicates nothing of knowledge sufficient for salvation or that the knowledge of the external universe is knowledge of God in substantive detail. Henry refines the point that general revelation is not salvific and leaves man in confrontation with God by stating, 'While he stresses in Romans 1 that the natural man suppresses the truth, Paul leaves no doubt that it is revealed truth that is being thwarted. God's invisible being has been clearly seen ever since the creation through his created reality; it is here that God universally confronts man' (Henry 1976: 2, 84). Further, G. C. Berkouwer reinforces the limitations of general revelation when he states, 'The purpose of [Romans 1] was to indicate the existence of a revelation of God in all the works of his hands, but that man, who comes into daily contact with this revelation, in his unrighteousness wards off this truth' (Berkouwer 1958: 16). The warding off of truth is sobering, yet the reality is inescapable as Henry describes the impact of Romans 1, 'In other words, no one anywhere at any time can escape the inner, secret, guilty knowledge of the true God and of his demand for spiritual submission and moral obedience' (Henry 1976: 2, 85).

\section{Content of General Revelation: The General Moral Conscience of Humanity (Romans 2)}

In Romans 2 Paul calls attention to the heathen who, while they lack the particularly revealed law of God, nonetheless by nature do what is expected in the law. This is to say, Paul is acknowledging the moral conformity of unbelievers who do not know the law. Berkouwer comments about this moral nature of humanity when he states, 'Apparently, life even in estrangement from God has not passed totally into nihilism and anarchy and lawlessness' (Berkouwer 1958: 20). The reason humanity has not passed completely into nihilism is the inextinguishable divine imaging of humanity in relationship 
between Creator and creation. Berkouwer comments, 'Paul does not delve deeper into this noteworthy appearance of conformity with the Law, but nevertheless by pointing to it, he emphasizes that even in estrangement some connection remains between man and God' (Berkouwer 1958: 20). Indispensable to Henry's theology of God as revealer is the ability of humanity to receive divine revelation. Henry attributes humanity's ability to know God's revelation to the imago dei, and even in light of the dramatic aftermath of the fall, 'the sense of justice survives universally as a property of humanity made in God's image' (Henry 1994: 87).

An important element of affirming general revelation is the interface of the communication of God in creation with the God given capacity of humanity to stand in relationship to the creator. For Henry, the imago dei as evidenced in general revelation is the basis for religious and moral epistemology. Henry states, "The Bible considers human reason and conscience a divinely given instrumentality for man's responsible existence in relationship to God and his fellow human beings... The revelation of God invades and penetrates the very mind and conscience of every man, despite the fact that, in face of this very revelation, men do not choose to know God (Romans 1:28)' (Henry 1976: 2, 130).

Following the outline of general revelation above, it is evident that general revelation provides apologetic contact points with the world of culture. In Acts 17, Paul engages the philosophers of his day in the Areopagus with creativity and boldness. One element of Paul's strategy was to utilize the resources of the pagan culture in his appeal for belief in Christ. What exactly was Paul's methodology in utilizing pagan resources in his appeal to Stoics and Epicureans? Berkouwer provides clarity that Paul was not utilizing the knowledge of the world as an authoritative source of divine revelation. Rather, Paul was utilizing his understanding of philosophy and religion to launch the Athenians toward repentance from their false beliefs and toward faith in Christ. Berkouwer states, 'In Acts 17 also we find a similar estimate of heathendom. Upon the Areopagus Paul calls for repentance (Acts 17:30), but he points out at the same time that, even in his apostasy, man is not loose from God and that this connection is evident in his life' (Berkouwer 1958: 20). The distinction between general and special revelation is the distinguishing factor for Berkouwer in asserting that Paul's use of philosophy was a contact point with the pagan culture rather than evidence of an independent knowledge of God. Berkouwer clarifies the relationship between general and special revelation when he states,

Because of man's involvement with the goodness of God's command, it is clear that the Church may not abandon its doctrine of general revelation. It may not proclaim this revelation as a second source of knowledge next to the revelation of God in Jesus Christ, but it may and must use it as a reminder of the God who 
does not abandon the world and who sets man in the midst of greatness and majesty. The message of the general revelation of God rings out the accusation (not the excuse) of man, yet simultaneously the gospel sounds out to the world (the Areopagus, Acts 17:30), so that life once more may be turned toward the living God who has displayed his love for the world (Berkouwer 1958: 22).

Given the limited content of general revelation, the detailed exploration of the creation through academic study, therefore, is not an exercise of knowing God directly. According to Henry, the general revelation of God is not 'to be confused with the notion of a talking cosmos... <Hear God!〉 is the biblical message, not <isten to nature!> Nature is God's created order, and in nature God presents himself. While this view runs counter to the naturalistic and pantheistic conceptualizations of nature, it involves no theological antagonism to nature as such, for the Bible sees the whole activity of nature as God's work' (Henry 1976: 2, 98).

\section{Misconceptions of General Revelation}

Henry's clarity regarding the limited revelatory content of general revelation stands in contrast to alternate approaches in contemporary theology. One such approach, which Henry addresses, is Natural Theology. Henry's concern is that a theology which claims it is possible to arrive at true knowledge of God by the powers of reason-in operation separate from divine revelation-elevates human reason to a position of autonomy. An overestimated, natural knowledge of God springs not from the disclosure of God to humanity, but through the attempts of natural reason. While general revelation is scripturally grounded and theologically significant, an expression of Natural Theology with strokes of epistemic autonomy independent of God is alien to Scripture. Berkouwer comments, 'It is clear that the Christian Church, in speaking of general revelation, never intended to assert that true knowledge of God is possible through the natural light of reason' (Berkouwer 1958: 15). The epistemic effects of the fall on humanity must be understood, as Henry highlights:

To be sure, neither Scripture nor human experience warrants the notion that, as a recipient of God's general revelation, man in sin can translate that revelation into undiluted truth about God, that is, into a 'natural theology'. God declares that his general revelation to man has a wholly different outcome. It is not into 'proofs' of the living God's existence, but into an occasion of revolt and estrangement that man the sinner turns the general disclosure of God (Henry 1976: 2, 86). 
And again, Henry emphasizes the limitations of natural theology.

God's universal disclosure in nature, history and to the human mind and conscience is not in dispute. What is rejected rather is the expectation that fallen man will translate general divine revelation into a natural theology that builds a secure bridge to special revelation; in that event special revelation has significance only as a crown that caps natural theology elaborated by man in sin (Henry 1976: 2, 117).

Humanity does not possess the ability to construct true knowledge of God apart from God's initiative to reveal Himself in particular ways. Otherwise, knowledge of God would be a human construct with God's revelation serving as the confirmation and crowning of humanity's achievement.

As a corollary to Natural Theology, Henry is wary of any approach to knowledge that understands the orders of creation as unmediated disclosure of God. Manifested particularly in modern theology through forms of pluralism or pantheism, the thinking may be subtly adopted by those who view the discovery of all truth as God's knowledge. Pluralism asserts the argument that all religions contain elements with hidden revelation of God. The 'history of religions' school in the nineteenth century called particular attention to world religions and made the plea that sufficient revelation is present in the plurality of religions to disclose God. Wolfhart Pannenberg asserted an approach to revelation which treads on pantheistic paths at points. He argued that the sum of world history itself, religious and nonreligious, reveals the God who has acted in history. In this light, Christian educators should be careful to not grant more weight to general revelation than it is meant to bear by framing the pursuit of knowledge in the world as discerning revelation about God Himself.

Henry is ardent in maintaining the distinctions between the Christian view of general revelation and the blurred lines of other worldviews when he says, 'There is in man under no circumstances any source of authentic theological knowledge... It is impossible to rise from experience of the space-time universe, from revelation-as-human-history, from independent anthropology, to a revelation of the living God. Divine revelation is neither a distillation of history nor of the spirit of man, but a transcendent disclosure of the Lord of history and man' (Henry 1976: 2, 121). For Henry, the proper orientation of knowledge to revelation is dependent on the difference between Creator and creation. Henry states, 'The self-revealing God is creator ex nihilo of the cosmic process, the ultimate cause of all that is. He is ontologically other than the created universe. All things continuously owe their being to his power... He also transcends the universe epistemologically and morally in that he is the stipulator and source of truth and good' (Henry 1983: 6, 37). Equating the truth of equations, history, physics, and 
human psychology to studying God Himself may lead evangelical educators to operate according to a pantheistic structure of knowledge.

Yet, according to Henry, while granting too much content and weight to general revelation is a concern, the opposite error must be avoided as well. In light of the affirmations provided in Scripture, general revelation should not be diminished or denied. General revelation, while limited in scope, does indicate that the world is the Lord's and He is concerned with matters of this world. The fall has not destroyed God's general revelation in nature and in humanity:

Despite man's loss of moral integrity and the threat to the integral unity of the imago posed by an inordinate will, even after the fall man is marked off from the animal world by facets of the original image, and lives out his creaturely existence within the forms of reason and morality that distinctively structure human experience. He stands ongoingly in responsible relationships to God and society (Henry 1976: 2, 136).

In the claim that the world is the Lord's and He stands permanently in relationship to His creation, we find theological relevance for the study of the world. It would be a mistake to entirely dismiss general revelation because to do so would leave Christian scholarship without necessary theological grounding. Henry provides reminder that the facts of the universe (and therefore every field of knowledge) are rooted in the reality of general revelation when he states, 'A general revelation of the Creator in his creation is integral to Christian doctrine founded upon Scripture and beyond that upon the factualites of the universe' (Henry 1976: 2, 83). In summary, general revelation is real revelation of God in creation that provides the orientation of knowledge to God, yet it is limited in scope and content.

\section{What is Special Revelation?}

We have moved from the overarching concept of revelation (that God has disclosed Himself in a variety of ways), to general revelation (that there is some limited content of God's disclosure available to all human beings), and now will consider special revelation. Special revelation is personal communication from the triune God, given to particular individuals at particular times by particular means. This information is disseminated through two means: Scripture and the incarnation of Christ. Incidentally, the latter is known to us through Scripture. Defining special revelation in relation to general revelation, Henry states, 'The Christian doctrine is that the living personal God directly and objectively manifests himself by intelligible words, commands and acts. God's redemptive revelation is given once for all at definite times and places... but he also is continually disclosed in na- 
ture and history and in and to the mind and conscience of man universally' (Henry 1984: 78).

\section{Special Revelation and the Bible}

We have established that special revelation encompasses God's specific communicative activity for the ultimate purpose of human redemption. Yet, we have not determined how God has provided access to His special revelation. Are we to study history to discern His revelation from the acts he has done? Are we to study anthropology in order to discern the light of God's revelation from the impact it has had on humanity? May it never be; we have a book! Through the Spirit-guided process of composition, circulation, collection, and canonization into a literary unit, God's special revelation is identified with the Bible. While we have started with a broad conceptualization of revelation that encompasses all the ways God has acted to communicate Himself, what is relevant for us today is that God has crowned His revelatory process by inspiring apostles and prophets to articulate His communication such that their words are revelation. Therefore, the Bible is the exclusive focus for special revelation.

Henry states, 'Is the Bible the written form of revelation? Is it the only form in which special revelation is available to us today, and one by which the Spirit of God has mediated to us whatever is of permanent importance in God's redemptive disclosure? The verdict of historic evangelical Christianity is unequivocal in these matters' (Henry 1957: 255). Henry affirms, yes, Scripture is the only material of relevance in special revelation. While much of the Bible is historical narrative, the revelatory locus of God's plan is in the words of Scripture. Henry makes clear the relationship between all of the activity of God in accomplishing His salvific revelation and the Bible we hold in our hands. Henry states,

If anything, the Bible, in exhibiting both the saving acts and their interpretation, is clearer than the acts viewed in isolation. The meaning of the saving events is given trustworthy expression in the inspired Scriptures, and is not merely suspended upon the inferences of experts in historical research. The inscripturation of special revelation is the objective culmination, therefore, of God's redemptive disclosure in special historical events and in propositions communicated to chosen prophets and apostles (Henry 1957: 256).

Again, Henry reinforces the point.

Special revelation is adjoined to general revelation, and revelational knowledge in all its forms belongs to the genus of knowledge generally. Special revelation is addressed to the whole man, and involves the communication of truths about God and His purposes as a factor in man's redemption; hence redemptive revelation comes by conceptual mediation through chosen prophets and apostles, is 
communicated in the form of words and propositions, and is inscripturated in canonical books (Henry 1957: 262).

The bottom line is that the Bible is the special revelation of God and deserving of our exclusive focus for knowing God. This is the point Henry makes when he states, '[T]he connection between special revelation and the Bible is strategically important, and [therefore] it must be stressed that the Scriptures are no mere appendage to special redemptive history, but an essential and climactic phase of it' (Henry 1957: 264).

\section{The Relationship between General and Special Revelation}

What then is the relationship between general revelation and special revelation? First, general revelation is intended to point individuals toward Christ. To this end, Berkouwer states, 'The confession of God's revelation in all the works of his hands does not demean the revelation in Christ to relative or lesser importance, but, on the contrary, serves rather to point toward that revelation in its saving character amid human estrangement from God' (Berkouwer 1958: 16). General revelation demonstrates to humanity on a universal plane that there is no righteousness to be had within, but that it must come from without. Henry states, 'The relation of general to special revelation is, first, that general revelation is the presupposition of redemptive revelation' (Henry 1976: 90). At the limitation of general revelation, the need for special revelation enters the picture as Henry claims, 'Indeed, only through special revelation do fallen human beings know the full implications of general revelation and of human sinfulness' (Henry 1976: 86). And again, 'Indeed, it is the Bible alone which enables man to assess fully the revelation in God's created works' (Henry 1976: 90).

Second, general revelation provides a background against which humanity stands in relationship to the Creator and true understanding of God's creation comes through the specificity of special revelation. Commenting to this end, Berkouwer states:

But the consideration of general revelation need not involve us in a theory of sources of equal value existing adjacent to each other. The relationship between general and special revelation is actually of an entirely different nature... More and more the fact is clear that the general revelation of God does not stand next to the special revelation but that special revelation opens our eyes to the greatness of God's works... (Berkouwer 1958: 18-19).

In summary, the foregoing discussion on revelation has demonstrated general revelation is limited in scope and content to (1) the knowledge of the existence and eternal nature of God, (2) the general moral conscience of humanity, and (3) the ability to reason from apologetic contact points in 
culture to make known special revelation. The Bible stands as the exclusive and full divine-disclosure to humanity. There is a wealth of application of Henry's clarity on revelation to be made in the world of learning. It is to this application that we now turn.

\section{The Axis of all that Orbits: Revelation and Education}

How do we relate the revelation of God to the pursuit of knowledge in a comprehensive university setting? The university setting by its very nature is one that seeks all available knowledge, and a Christian university must articulate with clarity how the revelation of God impacts the task of scholarship. Here we recall the metaphor of the axis and objects in orbit. Consider the following picture from Henry:

If ultimate reality is not irrational and ineffable, but is Logos; if ultimate reality is not impersonal, but is the Lord; if ultimate reality is not indifferent, but is Love; if it is in Christ Jesus that 'all things consist', if all things are 'of him, and through him, and unto him', if the cross is the central idea to which creation relates, if the Lamb of God was 'slain from the foundation of the world', if Jesus Christ is indeed 'the way, the truth and the life', if the Holy Spirit is to 'guide us into all truth', if there is 'no other name given among men whereby we must be saved', if the Church of Jesus Christ is 'the pillar and ground of truth', then it is dangerous to spawn a civilization that seeks truth without Christ. To apply genius and power for extending the orbit of worldly knowledge without reference to its axis of revelation in the Son of God is vain (Henry 1958: 310).

Jesus Christ is the axis of all reality, including every field of study and every piece of knowledge about God's creation which may be pursued in a university setting. The existence and knowledge of God's creation finds orbit around the Son, and this orientation provides the essential background for Christian scholarship.

\section{Axis: Jesus as the Center of all Knowledge}

The first priority of the Christian university is to order all pursuits of knowledge around the axis of the Son who created and sustains the universe. At many points throughout history, it was assumed that the Christian revelation of Jesus Christ stood at the center of all university study. Henry argues the organizing principle once assumed has been replaced by unfettered human autonomy when he states, 'If Christian truth about God and man supplied in medieval and early modern times the integrating principle of the university world, in the nineteenth century that role was optimistically captured by the autonomous human reason and the spirit of free inquiry' (Henry 1966: 107).

Henry helpfully re-states the orientation of the Lordship of Christ and knowledge as a contrast between Christian conviction permeating the edu- 
cational pursuit versus being a mere additive when he states, 'If the American colonial colleges arose within the conviction that Christianity as the one true religion provides the integrating factor in the realm of learning, in the present academic scene religion mainly serves as an additive to the liberal arts curriculum' (Henry 1966: 112). Again, Henry drives the point, 'For an evangelical campus, belief in the centrality of the self-revealing God, the singular divine incarnation of Jesus Christ, and the Bible as the norm of Christian truth must be not merely one characteristic among many others, but the unmistakable comprehensive and integrating fact' (Henry 1994: $100)$.

While perhaps quite basic, pursuing education with Jesus Christ at the center is not automatic and is increasingly uncommon. The history of western higher education demonstrates a pattern of drift away from this first and most basic commitment (Burtchaell 1998; Marsden 2000). The reality is that the effectiveness of an institution is compromised at the point of departure from Jesus Christ as the axis of all that occurs in university curriculum and life. Henry notes the diminished impact of institutions which stray when he states, 'Christ Jesus is the center of nature, history, man, and all the spheres of study. The Church silent on this message is no longer the Church; she tears the crown of glory from her Redeemer's brow, and substitutes another crown of thorns (Henry 1958: 311). Without orbit around the Son of God, the academic pursuit of truth and the social pursuit of transformation will be undermined. Again, Henry makes the point with reference to the social implications of Christ centered education.

Even the church colleges today tend to duplicate the failure of the non-religious campuses to comprehensively integrate the content of learning in terms of a rationally unified view of life and the world... College students may hitchhike a thousand miles and demonstrate day and night for the cause of social integration, but if they venture into the modern conflict for men's minds without coherently integrating the claims of pure religion and of academic learning, they will simply perpetuate in themselves the logical and psychological instability that haunts the larger intellectual world in our time (Henry 1966: 113).

Christ stands at the center of all reality and, in terms of revelation, that is a matter exclusively known by special revelation in Scripture. Therefore, Christian education can be built on no other foundation and yield to no authority higher than Scripture.

\section{Orbit: Knowledge of Creation}

Christian educators pursue scholarship and teaching in light of the fact that God stands in relation to the creation at all times. God stands in relation to unbelievers by providing common grace to all humanity. He stands in rela- 
tion to believers through enabling our activity in the world to become service to God and to others in His name. This does not mean that all knowledge available to humanity is knowledge of God Himself and warrants the label 'revelation.' It does mean that all knowledge is oriented around an absolute organizing principle, specifically the Lord Himself, Jesus Christ. Henry describes the distinction between revelation and knowledge of creation in several subtle, yet helpful ways. Henry acknowledges the difference in nature between revelation as the absolute source of meaning and value, versus the finite nature of knowledge acquired through academic study.

To an historically given divine revelation Judaism and Christianity trace their confidence that a sovereign personal God is the creator of the universe and the absolute source of meaning and value. This revelation, in contrast to finite human speculation and naturally acquired knowledge about reality, they consider a permanently valid divine disclosure reaching back to ancient patriarchal and prophetic times (Henry 1984: 77).

Speaking of the study of physics, Henry states general revelation provides the backdrop of divine reality for all thought.

The general revelation, moreover, does not stop with this divine confrontation of man (the scientist included) in external nature. The scientist is faced not only by light from the outside, but by an inner light; the Logos is manifested in the conscience and mind of man, not simply in nature and history. And this inner and outer revelation interact and agitate each other constantly, supplying the silent background of all human thought and action. Even before the scientist comes to decision about nature... he is enmeshed in inner spiritual tension as a responsible moral agent (Henry 1960: 36).

The reality of axis and orbit means there is an order and priority to revealed truths over and against natural knowledge. The consequence of this order is that divine revelation holds relevance to every area of knowledge. In light of this relevance, the task of the Christian scholar is to make plain the manner in which revelation impacts his field of study. According to Henry, revelation holds an interpretive role over worldly knowledge, as he states, 'Christian education is nothing if not theistic. Since the knowledge of God crowns all other knowledge, and interprets and coordinates it, Christian education must maintain academic visibility for theology' (Henry 1966: 117). The orientation of axis and orbit does not diminish the pursuit of non-revelational knowledge. Rather, the fact that all knowledge finds orbit around Jesus Christ allows the study of any field to be an expression of worship because the authority of the axis is acknowledged. Henry states, 
The Christian Church historically has regarded education and religion as complementary exposures on the vistas of revelation; it champions therefore both the desirability of the scholarly mind and the indispensability of the new birth. The church with an intellectually uncircumscribed vision of reality once had a stake in the whole truth so extensively that she became the mother of popular education; while in her best days of moral earnestness the campus had such a stake in spiritual realities that learning was crowned with the knowledge of revealed religion (Henry 1966: 114).

What are Christian scholars doing when they pursue knowledge in academic disciplines? The scholar is studying the world of knowledge which is distinct from, yet orbits around Jesus Christ as the axis of ultimate reality. In this regard, knowledge of God is properly attributed to the realm of divinely initiated revelation, and study of the world is attributed to the pursuit of understanding what God has created. Here we have two different categories of knowledge which must be properly associated in order for effective Christian scholarship.

\section{Henry's Vision for a Christian University}

We now undertake the task of translating the orientation of axis and orbit to the educational mission of a Christian university. Implementing this vision creates specific habits in university life, and particularly in the research and teaching efforts of the faculty. First, faculty are to understand the marketplace of ideas and present the Christian approach with clarity and conviction. Henry states,

In the contemporary struggle for truth, [Christian professors] are called to vindicate Christian convictions in a highly competitive ideological market. Precisely this opportunity to engage in the modern clash of ideas and ideals now constitutes the most exciting and demanding aspect of Christian education. As Christianity's great apostle, university-trained in Tarsus, went on to Athens to engage Stoics and Epicureans over life's ultimate issues, so evangelical educators in modern times must engage in the ideological struggle with conviction, courage, and competence (Henry 1966: 115).

Second, orienting all knowledge around Jesus Christ impacts life outside the classroom. The breadth of life experience orbits around Christ, and therefore the university is concerned to demonstrate how all of human life should display the proper orbit. Henry comments on the holistic nature of education by stating, 'Because the Christian religion stresses the importance of reason, not simply will and emotion, it has a continuing stake in the arena of culture generally and in the realm of education specifically. For Christianity exalts God as Lord of the minds of men, and under God seeks the 
spiritual and intelligible integration of all of life's experience' (Henry 1958: 307).

Third, social transformation follows from a proper orientation of knowledge and revelation. The Christian scholar bears strategic opportunity for social impact rooted in his ability to bring together knowledge of the biblical revelation and expertise in his field of study. To this end, Henry comments, 'Traditionally, colleges and universities have served as society's critical intellectual center. Within that academic framework evangelical Christians must inject and articulate the mind-set and heartbeat of revealed religion' (Henry 1994: 77). Henry provides an apologetic note to motivate scholars to advocate for Christianity's station in the marketplace of ideas when he states,

Unless Christian education publicly expounds its way of knowing God, strenuously proclaims universally valid truth, and clearly identifies the criteria for testing and verifying the knowledge-claims we make, then the Christian view of God and the world will survive but as a fading oddity in an academic world that questions its legitimacy and appropriateness (Henry 1994: 93).

\section{Concluding Thoughts about Christian Academics}

First, Christian scholarship must assign proper content, weight, and roles to general revelation and special revelation. According to the Bible, general revelation is a real and affirmed aspect of God's communication about Himself to all of humanity. However, the content of general revelation is limited to the existence of a divine power and eternal nature, the moral nature of humanity, and the imago dei that provides all of humanity the ability to be knowers of God's divine revelation. Due to the sin nature, all of humanity rebels against general revelation to the effect that it is not salvific, it does not provide substantive insight about God, and it results only in the condemnation of humanity. Special revelation is the particular initiative of God to communicate to the entirety of humanity about Himself for the purpose of redemption. The final and accessible manifestation of special revelation is the written Word of God in the canonical books of the Bible. In light of the Scriptures revealed by the Holy Spirit, regenerated individuals may properly understand the world around them in the light of special revelation. The foundational and unifying nature of inscripturated revelation illumines all of God's creation. The specific unifying truth of Scripture is that Jesus Christ is the Lord of all creation and deserving of worship.

Second, Christian scholars must pursue the axis and orbit with excellence. All fields of study have the same axis, yet we have a diversity of subjects in orbit. View knowledge in relation to Jesus Christ as the explanatory principle of all of reality. Built on the distinction between revelation and knowledge of creation, studying the world of knowledge is not the same as 
studying general revelation. The Christian scholar does not pursue knowledge of God's creation, learn the skills to create as an image bearer, or study the past work of image bearers as the study of God Himself. Rather, the study of God's world is to be properly oriented as pursuing the facts of reality and becoming image bearers properly oriented in orbit around the axis of Jesus Christ. Practically, this means the pursuit of knowledge is integrated around a central conviction and is a matter of the love of God and love of neighbor, which provides ample motivation for excellence in scholarship.

Third, Christian scholars must deconstruct conceptual structures of knowledge incongruent with the biblical revelation and rebuild them with fidelity to the Lordship of Christ. All theories of knowledge are built on presuppositions. Christian scholarship bears responsibility to investigate the breadth of conceptual structures in any field. This is done by evaluating the whole of the system, the components with which it is constructed, and the presuppositions upon which it is built. A great many contemporary systems of thought in a variety of disciplines are built on presuppositions contrary to Christian revelation or, at a minimum, these systems have adopted components inconsistent with Christianity. On this point, Henry is worth reading at length.

Liberal learning surveys all the influential options on the contemporary horizon. In the modern world, the alternatives to historic Christianity carry twentieth century names and nuances, and we need to relate our faith relevantly to these modern frontiers. We need to know these alternatives to faith as well as their own advocates know them-to know them through and through, as it were. We need to be skillful not only at external criticism from the standpoint of Scripture, but at internal criticism from the standpoint of intrinsic inconsistencies, of inherent weaknesses. No student achieves this ability without earnest academic engagement. A mark of a scholar is his ability to present an alien point of view fairly on its own presuppositions. We must present non-Christian theories so accurately that their advocates will marvel that this bold echo of their own convictions seems so unpersuasive to us, and we likewise will insist on such fairness in their exposition of the Christian view of God and the world that we shall not suspect that others reject what they do not really understand but only caricature. If we want the academic world to know whom we have believed, we are likely to impress others only if they are assured also that we genuinely know what we do not believe (Henry 1966: 115).

In place of incongruent structures, scholars should construct conceptual structures that order the facts of reality within one's discipline according to revealed truth. Henry casts this vision in the field of science in the following passage. 
Let there be scientists who behold God's glory and nature and not only impersonal processes; anthropologists who affirm the image of God in man and not only an animal ancestry; philosophers who stress that fear of God is the beginning of wisdom rather than the beginning of mythology; moralists who emphasize God's commandments rather than the tolerances of modern culture; artists who set agape to music and poetry and who will capture our now wicked world of words for whatever is good and godly; let us have intellectual leaders who offer life and hope to civilization that has missed the way and needs to be alerted again to the incomparable greatness and grace of Jesus Christ (Henry 1983: 154).

Fourth, Christian scholars must provide an apologetic oriented around Jesus Christ as the focus of special revelation through comprehensive evaluation of each field of knowledge. The imago dei undergirds human rationality for the unbelieving academic world and preserves, albeit seriously marred, the ability to argue from the truth of creation to make clear to the world the differing foundations of the secular and Christian worldviews. While pursuing excellence in all aspects of a field of knowledge, Christian scholars should appeal to apologetic contact points to call unbelievers to repentance under the Gospel of Christ. Further, launching from those apologetic contact points, scholars may demonstrate to believing students rationale for confidence in the intelligibility of Christianity. As a community of Christian scholars pursues the axis and orbit with excellence, the potential is magnificent. Henry deserves the final word to hold forth the vision: 'If the influence of a great Christian university could permeate educational enterprise throughout the world, if every realm of learning could face with sobriety the supremacy of Jesus Christ, who can predict what great blessing even one nation-may it yet be America-could bring to the world, and to the cause of truth?' (Henry 1958: 312)

\section{Bibliography}

Athanasius (2011) in Behr J (trans) On the Incarnation. Yonkers, NY: St Vladimir's Seminary Press.

Berkouwer GC (1958) General and Special Divine Revelation. In Henry CFH (ed) Revelation and the Bible. Grand Rapids, MI: Baker.

Burtchaell, JT (1998) The Dying of the Light: The Disengagement of Colleges and Universities from Their Christian Churches. Grand Rapids, MI: Eerdmans.

Fackre G (1993) Ecumenical Faith in Evangelical Perspective. Grand Rapids, MI: Eerdmans.

Henry CFH (1957) Divine Revelation and the Bible. In Walvoord J (ed) Inspiration and Interpretation. Grand Rapids, MI: Eerdmans. 
Henry CFH (1958) Christian Education and the World of Culture. Mennonite Quarterly Review 32(4): 307-13.

Henry CFH (1960) Science and God's Revelation in Nature. Bulletin of the Evangelical Theological Society 3(2): 25-36.

Henry CFH (1966) The God Who Shows Himself. Waco, TX: Word Books.

Henry CFH (1976-1983) God, Revelation, and Authority, 6 volumes. Wheaton, IL: Crossway.

Henry CFH (1983) Presentation given on June 23, 1983, at the Mayflower Hotel in Washington DC, Henry Papers. In Strachan O (ed) Awakening the Evangelical Mind. Grand Rapids, MI: Zondervan.

Henry CFH (1984) The Priority of Divine Revelation: A Review Article. Journal of the Evangelical Theological Society 27(1): 77-92.

Henry CFH (1988) Twilight of a Great Civilization: The Drift Toward NeoPaganism. Wheaton, IL: Crossway.

Henry CFH (1994) God of this Age or God of the Ages? Nashville, TN: Broadman \& Holman Publishers.

Marsden G (2000) The Soul of the American University: From Protestant Establishment to Established Nonbelief. Bridgewater, NJ: Replica Books.

Olsen RE (2005) The SCM Press A-Z of Evangelical Theology. London: SCM.

Rosell G (2008) The Surprising Work of God. Grand Rapids, MI: Baker.

Strachan O (2015) Awakening the Evangelical Mind: An Intellectual History of the Neo-Evangelical Movement. Grand Rapids, MI: Zondervan.

Trueman C (2000) Admiring the Sistine Chapel: Reflections on Carl F. H. Henry's God, Revelation, and Authority. Themelios 25(2): 48-58. 